\title{
The Application of Project Teaching Method in Hydraulic Transmission and Control based on CDIO
}

\author{
Lu Qianqian ${ }^{\mathrm{a},}{ }^{*}$, Xia Chunlin ${ }^{\mathrm{b}}$ \\ Zhejiang University City College, Hangzhou, China, 310015 \\ aluqianqian@zucc.edu.cn, bxiacl@zucc.edu.cn
}

Keywords: CDIO, hydraulic transmission and control, Project Teaching Method

\begin{abstract}
A project-oriented teaching reform in the course of hydraulic transmission and control is provided based on the CDIO engineering teaching philosophy. The paper takes plastic injection molding machine hydraulic system as an example to design and simulate the hydraulic system according to the working principle and design requirements. And the specific design of the project implementation is carried out in accordance with the approach: Conceive-DesignImplement-Operate. During the implementation process, students not only have a deep understanding of the hydraulic basic knowledge, and learn to use hydraulic simulation software to design and analyze hydraulic system, but also can do self-correction of their work according to design and task requirements. The practice results show that under the collaboration and the guidance of teachers, the practice of project-oriented teaching method not only improves the students' interest in learning and self-learning ability, but also develops their problem-finding and problem-solving skills. In a word, the practice improves students the level of expertise and attainment, which helps them to be qualified talents for mechanical and electrical engineering.
\end{abstract}

\section{Introduction}

The CDIO engineering education model has been globally accepted by international engineering education reforms, which take all phases of the lifecycle of products to capture students' passion and allows students to initiatively involve in the learning mode between the course and practice. As for the course of hydraulic transmission and control, it is urgent for teachers to stimulate students' initiative and combine the practice with classroom teaching in the theory-based classroom[1].

Hydraulic transmission and control is the science which is primarily about the general rules and specific applications. It is not only a professional course of mechanics, but also a course that can be used in engineering practice[2,3]. In applied undergraduate training system, how to construct the knowledge structure of the course, improve teaching methods to improve teaching effectiveness, and enhance the innovative awareness and improve the practice the capacity and ability to collaboration, to meet teaching requirements become an urgent subject.

Currently, a lot of defects exist in the teaching method of hydraulic transmission and control. For example, too much time is spending on emphasizing the theoretical knowledge and neglecting the practical content of teaching, and some teachers stress the integrity of knowledge which is lack of teaching orientation[4]. While in applied undergraduate college, it is vertical to emphasize the practicality of the course and reorganize the content of course in order to be more pertinent when teaching. The philosophy of the CDIO approach to engineering education captures essential features of a modern engineering education to meet the challenge by educating students as well-rounded engineers who understand how to Conceive-Design-Implement-Operate complex, so these require the teaching task to be done accordingly, as shows in Figure 1. 


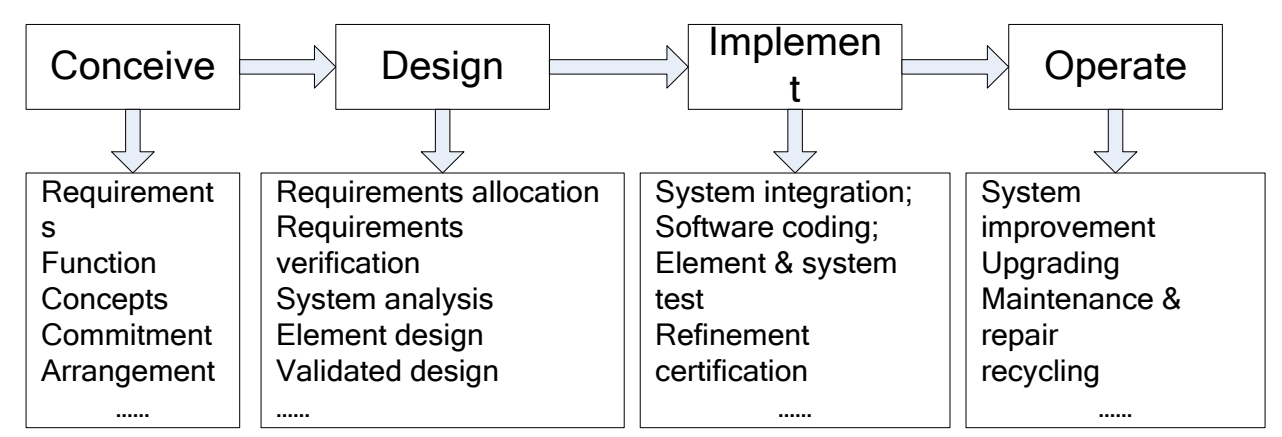

Figure 1 Tasks of the four main phases-Conceive, Design, Implement, Operate

\section{The overall design of project teaching method of hydraulic transmission and control}

The project teaching method of hydraulic transmission and control based on CDIO approach is implement the four phases- Conceive, Design, Implement and Operate through an engineering project during teaching process, to make students learn initiatively and make the learning process with plan, purpose and evaluation. This paper takes the project-the hydraulic system design of SZ-250A type plastic injection molding machine as an example to illustrate the process of teaching reform.

1) Firstly, some basic information should be introduced to the students about the plastic injection molding machine. SZ-250A injection molding machine belongs to the small and medium-sized injection molding machine, whose maximum injection volume is $250 \mathrm{~g}$ each time. The machine melts the grain-like plastic by heating to flowing state, and injects the flow into mold cavity quickly at high pressure. The molten state of the plastic in the cavity keeps pressure for some time as long as cooling to model. This kind of machine can manufacture complex shape, precision size plastic products or with metal inserts. The mainly working parts of this injection molding machine are driven by hydraulic.

2) Secondly, according to the working principle and design requirements of the plastic injection machine, students working as a group should conceive the hydraulic schematic diagram to meet a serious cyclic action, like clamping, injection seat moving, injection, holding pressure and pushing out the molded product, etc. and they also should figure out how to fulfill these cyclic action in sequence at certain pressure and speed, they also have to select hydraulic components with appropriate function, and some other problems. Under this situation, students need to discuss and conceive on the condition of pre-learnt knowledge and searching information to accomplish their first step design.

3) Thirdly, in order to achieve the requirements, element and system design, that means more detail design, should be done. According to the functions of the system, it is an efficient way to design system separately by functional circuit, such as, circuit of clamping at different speed or at different pressure, circuit of injection seat move, injection circuit and circuit of pushing out the molded product, etc. in order to fulfill these separate function circuit, the knowledge of circuit design should be mastered, including speed control circuit, pressure control circuit and direction control circuit. Furthermore, how to combine these designed functional circuits into the whole system, students should clear about key points of system analysis and design. After the schematic design, the parameter of hydraulic elements and the logic relationship of actions should be decided for the next step.

4) Fourthly, according to the design step, student would use simulation software- FluidSIM or AMESim to build simulation model and set parameters for each elements, by running the model to check whether the kinematic parameters and force parameters is fit for the requirement.

5) Lastly, students should evaluate their design results and feedback timely to re-design where there is some part that doesn't suit for the requirements. Meantime, all design process should be neatened and compiled to fixed format document as a report for the project. 


\section{Implementation steps}

The aim of the teaching reform is to improve students' interests, professional skills and abilities through a hydraulic system analysis and design project. The project implementation steps of SZ-250A type plastic injection molding machine are shown in Figure 2.

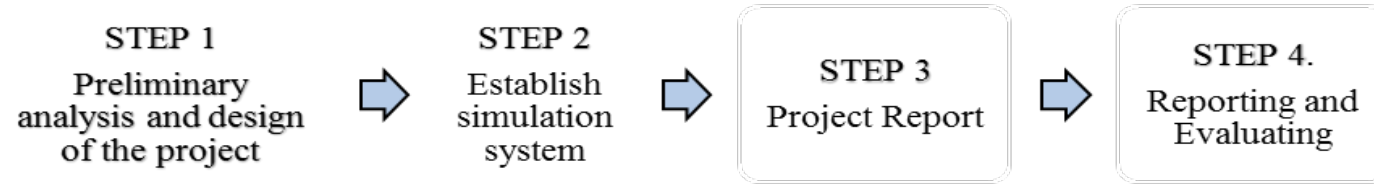

Figure 2 the steps of project implementation

In the first step, the assignment of tasks between teachers and students is shown in Table 1, with clear teaching objectives and school hours.

Table 1 The teaching implementation of STEP 1

\begin{tabular}{|c|c|c|c|}
\hline Teacher's tasks & Students' tasks & Teaching target & Hours \\
\hline $\begin{array}{l}\text { 1. Grouping: A group of three } \\
\text { students, a clear division of } \\
\text { labor. } \\
\text { 2. Task layout: issuing a } \\
\text { mission statement and } \\
\text { schedule. } \\
\text { 3. Explain the working } \\
\text { principle and design } \\
\text { requirements of the machine, } \\
\text { and introduce design method } \\
\text { of the hydraulic system. }\end{array}$ & $\begin{array}{l}\text { 1. A clear division of labor, and } \\
\text { schedule members' mission. } \\
\text { 2. Searching information and } \\
\text { learn the working principle and } \\
\text { process of the molding } \\
\text { machines. } \\
\text { 3.Preliminary conceive the } \\
\text { functional modules of the } \\
\text { system according to the design } \\
\text { requirements }\end{array}$ & $\begin{array}{l}\text { 1. Level of knowledge: } \\
\text { master the hydraulic } \\
\text { system working principle } \\
\text { and design methods, as } \\
\text { well as functions of } \\
\text { components. } \\
\text { 2.Level of ability : } \\
\text { literature } \\
\text { self-learning, } \\
\text { collaboration }\end{array}$ & $\begin{array}{c}3+3 \\
\text { (Curricular } \\
\quad \& \\
\text { Extracurric } \\
\text { ular hours) }\end{array}$ \\
\hline
\end{tabular}

In order to combine the design and analysis software with the current curriculum project, the second step helps the students master the use of software and deepen the design and analysis ability of hydraulic system through extracurricular study and group discussion. Specific implementation is shown in Table 2.

Table 2 The teaching implementation of STEP 2

\begin{tabular}{|c|c|c|c|}
\hline & asks & $\mathrm{Te}$ & \\
\hline $\begin{array}{l}\text { 1. Introduce the operation of } \\
\text { simulation software. } \\
\text { 2. Introduce combination } \\
\text { separate function modules } \\
\text { into whole system. }\end{array}$ & $\begin{array}{l}\text { 1. Learn to use software; } \\
\text { 2. Establish the hydraulic } \\
\text { simulation model } \\
\text { 3. Simulate the model and } \\
\text { analysis system's characters. }\end{array}$ & $\begin{array}{l}\text { 1. Level of Knowledge: } \\
\text { master the use of software } \\
2 \text {. Level of Capacity: } \\
\text { simulation design, analytical } \\
\text { and verification capacity. }\end{array}$ & $\begin{array}{c}+6 \\
\text { (Curricular } \\
\quad \& \\
\text { Extracurric } \\
\text { ular hours) }\end{array}$ \\
\hline
\end{tabular}

In order to train the students' ability of design and analysis results, the third step help students to comb the whole process of the project from conception, to design and analysis in the form of project report. The concrete implementation is shown in Table 3.

Table 3 The teaching implementation of STEP 3

\begin{tabular}{|c|c|c|c|}
\hline Teac & Students' tasks & Teaching target & Hours \\
\hline $\begin{array}{l}\text { 1. Set report format and } \\
\text { content requirements; } \\
\text { 2. Self-evaluation and } \\
\text { mutual-evaluation in group } \\
\text { and between groups }\end{array}$ & $\begin{array}{l}\text { 1. Complete document of the } \\
\text { project report in professional } \\
\text { paper format. } \\
2 \text { Describe the process of the } \\
\text { project, including: conceive, } \\
\text { design, problems, solutions, etc. }\end{array}$ & $\begin{array}{l}1 \text { Level of Knowledge: } \\
\text { grasp content and process } \\
\text { of the hydraulic design } \\
2 \text { Level of capacity: use } \\
\text { office software skillfully; } \\
\text { Professional writing ability }\end{array}$ & $\begin{array}{c}3+6 \\
\text { (Curricular } \\
\quad \& \\
\text { Extracurric } \\
\text { ular hours) }\end{array}$ \\
\hline
\end{tabular}

The forth step is to evaluates the students according to introduction of the design and combine with the students' self-presentation and self-evaluation, which is a better way to evaluates the students' theoretical knowledge under the condition of insufficient hardware, the implementation is 
shown in Table 4.

Table 4 The teaching implementation of STEP 4

\begin{tabular}{|c|c|c|c|}
\hline Teacher's tasks & Students' tasks & Teaching target & Hours \\
\hline $\begin{array}{l}\text { 1. Select outstanding teams to } \\
\text { report in class, record, evaluate } \\
\text { and collect materials. } \\
\text { 2. File the materials and sum } \\
\text { up relative merits during the } \\
\text { project to get improvements. }\end{array}$ & $\begin{array}{l}\text { 1. report, self-evaluation and } \\
\text { mutual-evaluation } \\
\text { 2. Hand materials, including } \\
\text { schedule, appraisal forms, the } \\
\text { score sheet, simulation model, } \\
\text { project reports. }\end{array}$ & $\begin{array}{l}\text { 1. Level of Knowledge: } \\
\text { learn from excellent team } \\
\text { and optimize its own } \\
\text { results } \\
\text { 2. Level of Capacity: oral } \\
\text { expression ability. }\end{array}$ & $\begin{array}{c}3+3 \\
\text { (Curricular \& } \\
\text { Extracurricul } \\
\text { ar hours) }\end{array}$ \\
\hline
\end{tabular}

\section{Implementation effects}

From the reform, firstly, it improves students' ability to learn. They become active in class instead of passively listen to the teacher and more initiate to learn knowledge, meanwhile, their abilities of searching information and self-learning have graduate enhanced. secondly, students' learning effect has been improved. During the whole system design and system simulation, they can mastery the basic knowledge and system design and combine theoretical knowledge with practice to stimulate their critical thought, problem-solving ability and cultivate teamwork spirit.

\section{Conclusion}

In short, project teaching method turns the act of teacher into designing and planning of the learning process and organizes students into learning, while students spend more time and energy to finish the project as a pre-engineer. the course-hydraulic transmission and control, by using this teaching method under the lack of experiment situation, attracts students' attention and stimulates their learning interests, so that they set a solid foundation of professional knowledge and engineering design. Through training like this, students can be trained to satisfy the overall requirements of qualified mechanical engineer to fully adapt to the professional and competence requirements of the job in future.

\section{Acknowledgment}

This work is supported by the Forth education reform project by school of engineering (GC4-1015) and the 8th key Courses construction fund of ZUCC (SJ1503).

\section{References}

[1] Crawley, E. F., Malmqvist, J., Östlund, S., Brodeur, D. R., and Edström, K. (2014). The cdio approach. Rethinking Engineering Education, 19(5), 1-5.

[2] HU S. G. (2008). Practice-oriented course construction and teaching methods of course of hydraulic and pneumatics transmission. Journal of Changzhou Institute of Technology, 1, 90-92.

[3] Zhang, P. G., Zhao, Y. L. and LU J. M. (2010). Chatting educational reform of "hydraulic transmission and control” curriculum with the CDIO pattern. Chinese Hydraulics \& Pneumatics, 8, 23-25.

[4] LI Q X, Ding S F, Huang Q and WU Z J. (2016) Experimental items design and teaching method discussion of hydraulic and pneumatic transmission course. Laboratory Science, 19(2), 2016.129-131. 